\title{
PENGARUH PRESTASI BELAJAR MATA PELAJARAN PRODUKTIF DAN EFEKTIVITAS LABORATORIUM PELATIHAN USAHA TERHADAP MINAT WIRAUSAHA SISWA
}

\author{
Tri Wulaning Purnami, SMK Negeri 1 Surabaya \\ tiwipurnami@gmail.com
}

\begin{abstract}
ABSTRAK
Tujuan penelitian ini adalah (1) menganalisis pengaruh prestasi belajar mata pelajaran produktif terhadap minat wirausaha siswa; (2) menganalisis pengaruh efektivitas laboratorium pelatihan usaha terhadap minat wirausaha siswa; (3) menganalisis pengaruh prestasi belajar mata pelajaran produktif dan efektivitas laboratorium pelatihan usaha terhadap minat wirausaha siswa. Sampel secara proposional random sampling sebanyak 254 siswa kelas XI Bisnis Manajemen (Bismen) dari tiga sekolah yaitu SMKN 1 Surabaya, SMKN 4 Surabaya, dan SMKN 10 Surabaya. Metode pengumpulan data menggunakan dokumentasi dan angket. Teknik analisa data menggunakan uji statistik regresi linear berganda, dengan hasil penelitian (1) terdapat pengaruh signifikan positif prestasi belajar mata pelajaran produktif terhadap minat wirausaha siswa; (2) terdapat pengaruh yang positif dan tidak signifikan efektivitas laboratorium pelatihan usaha terhadap minat wirausaha siswa; (3) ada pengaruh signifikan positif prestasi belajar mata pelajaran produktif dan efektivitas laboratorium pelatihan usaha terhadap minat wirausaha siswa.
\end{abstract}

Kata Kunci: Prestasi Belajar Mata Pelajaran Produktif, Efektivitas Laboratorium Pelatihan Usaha, Minat Wirausaha Siswa

\begin{abstract}
The purpose of this study is: (1) analyze the influence of the learning achievement of productive subjects of the entrepreneurial interests of students; (2) analyze the influence of the effectiveness of business training laboratory for students' entrepreneurial interest. Samples proportional random sampling 254 students of class XI Bismen of three schools namely SMK 1 Surabaya, SMKN 4 Surabaya, Surabaya SMKN 10. Methods of data collection using documentation and questionnaires. Data analysis using multiple linear regression statistical test, $F$ test and test, analysis using IBM SPSS Statistics 22 programs. Results of the study: (1) there is a significant positive influence learning achievement of productive subjects to the students' entrepreneurial interest; (2) there is a positive influence and insignificant effectiveness of business training laboratory for students' entrepreneurial interest; (3) there is a significant positive influence learning achievement of productive subjects and effectiveness of business training laboratory for students' entrepreneurial interest.
\end{abstract}

Keywords: Achievement on Productive Subjects, Effectiveness of Business Training Laboratory, students' entrepreneurial interest 


\section{PENDAHULUAN}

Dari hasil observasi diketahui bahwa minat wirausaha siswa masih rendah, yaitu $\pm 10 \%$ dari 40 siswa. Begitu juga pada observasi yang dilakukan ketika siswa melakukan praktek kewirausahaan, rata-rata siswa menyatakan senang dengan adanya praktek kewirausahaan $( \pm 90 \%)$. Tetapi ternyata dari $\pm 90 \%$ tersebut, hanya $\pm 10 \%$ yang menyatakan berminat berwirausaha. Hal ini menunjukkan rendahnya pengaruh praktek kewirausahaan terhadap minat wirausaha siswa di SMK Negeri Surabaya. Hasil penelitian Hussain, et.al. (2010) menyebutkan bahwa pilihan siswa terlibat atau tidak dalam bentuk kegiatan kewirausahaan (misalnya bisnis keluarga atau penciptaan usaha baru) dapat dipengaruhi oleh pengalaman mereka, pendidikan kewirausahaan serta dengan model peran keluarga atau pengusaha.

Minat wirausaha bisa dipelajari melalui disiplin ilmu kewirausahaan yang diajarkan di lembaga pendidikan formal, juga dapat terbentuk dari pemilihan peminatan pada saat siswa diterima di SMK/MAK. Hasil penelitian Manuere, et.al. (2013) menyebutkan pendidikan kewirausahaan sangat penting, dan terdapat $60 \%$ dari siswa menunjukkan kesediaan mereka untuk memulai bisnis setelah lulus. Tetapi penelitian Abdullah dan Norhlilmatun (2013) secara mengejutkan mengungkapkan bahwa faktor pengetahuan tidak signifikan dalam mempengaruhi minat pemuda untuk menjadi pengusaha. Hasil penelitian yang berbeda tentang pengaruh disiplin ilmu terhadap minat wirausaha menarik untuk diteliti lebih lanjut, khususnya tentang pengaruh prestasi belajar mata pelajaran produktif terhadap minat wirausaha siswa di SMK Negeri Surabaya.

Untuk menunjang keberhasilan tujuan pembelajaran mata pelajaran produktif diperlukan adanya pusat sumber belajar (resources centre/learning resources) yang disebut dengan laboratorium, merupakan tempat pelatihan usaha siswa Bidang Keahlian Bismen. Sebagai resources centre/learning resources, laboratorium pelatihan usaha yang berada di lingkungan sekolah merupakan sarana belajar teori dan praktek siswa pada mata pelajaran produktif Bidang Keahlian Bismen. Rohman (2006) dalam jurnalnya menyampaikan bahwa Unit Produksi (UP) dapat digunakan sebagai alternatif pelatihan kecakapan hidup (lifeskill) dan kecakapan berwirusaha, yang mewakili pelatihan di industri secara simulatif. Didukung oleh penelitian Jerry (2013) yang menyimpulkan bahwa terdapat hubungan yang positif dan signifikan antara prestasi belajar kewirausahaan dan hasil praktek kerja terhadap minat berwirausaha siswa. Untuk itu perlu adanya penelitian lebih lanjut, khususnya tentang efektivitas laboratorium pelatihan usaha terhadap minat wirausaha siswa di SMK Negeri 1 Surabaya.

Menurut Slameto (2010) minat adalah suatu rasa lebih suka dan rasa ketertarikan pada suatu hal atau aktivitas, tanpa ada yang menyuruh. Minat besar pengaruhnya terhadap belajar, karena bila bahan pelajaran yang dipelajari tidak sesuai dengan minat siswa, siswa tidak akan belajar dengan sebaik-baiknya. Seperti yang disampaikan Hilgard (Slameto, 2010:57) tentang minat "interest is persistent tendency to pay attention to and enjoy some activity or content". Menurut Al-Mighwar (2011) bahwa sepanjang masa remaja, minat yang dibawa dari masa kanak-kanak cenderung berkurang dan diganti oleh minat yang lebih matang. Sedangkan menurut Hurlock (2010) minat (interest) merupakan sumber 
motivasi yang mendorong orang untuk melakukan apa yang mereka inginkan bila mereka bebas memilih. Minat lebih tetap (presistence) karena minat memuaskan kebutuhan yang penting dalam kehidupan seseorang. Secara etimologis, Fu'adi (2009) menyebutkan wirausaha berasal dari kata "wira" dan "usaha". Wira berarti berani, utama, dan berdiri sendiri. Kata usaha berarti kegiatan untuk memenuhi kebutuhan. Maka istilah wirausaha dalam arti luas dimaksudkan keberanian dalam memenuhi kebutuhan serta memecahkan permasalahan hidup dengan kekuatan yang ada pada diri sendiri. Menurut Alma (2011) dorongan yang membentuk wirausaha pada siswa didorong oleh guru sekolah terutama yang memberikan mata pelajaran kewirausahaan. Begitu pun Suryana (2014) menjelaskan bahwa kewirausahaan tidak hanya bakat bawaan sejak lahir atau urusan pengalaman lapangan, tetapi juga dapat dipelajari dan diajarkan. Dipertegas pula oleh Suherman (2010) bahwa hasil akhir yang ingin dicapai dari pembelajaran kewirausahaan ialah tertanam atau terbentuknya jiwa wirausaha pada diri seseorang, sehingga yang bersangkutan menjadi wirausaha dengan kompetensinya.

Dalam penelitiannya, Longenecker, et.al. (2001) menyebutkan bahwa wirausaha adalah seorang pembuat keputusan yang membantu terbentuknya sistem ekonomi perusahaan yang bebas. Dipertegas oleh Davey dan Plewa (2011) yang menyebutkan, kewirausahaan didefinisikan sebagai pola pikir dan proses untuk menciptakan dan mengembangkan kegiatan ekonomi dengan memadukan pengambilan risiko, kreativitas dan/atau inovasi dengan manajemen yang baik, dalam organisasi baru atau yang sudah ada.

Suherman (2010) menyebutkan bahwa seorang wirausaha merupakan seorang yang kreatif dan inovatif. Di samping kreatif dan inovatif, seorang wirausaha pun memiliki sifat-sifat atau karakteristik atau ciri-ciri tertentu. Begitu juga Usman (dalam Suryana, 2014) menyebutkan bahwa secara umum wirausaha memiliki dua peran, yaitu (1) Sebagai penemu; wirausaha berperan dalam menemukan dan menciptakan: (a) produk baru, (b) teknologi baru, (c) ide-ide baru, (d) organisasi usaha baru. (2) Sebagai perencana; wirausaha berperan dalam merancang: (a) perencanaan perusahaan, (b) strategi pemasaran, (c) ide-ide dalam perusahaan, (d) organisasi perusahan.

Dari pendapat-pendapat tersebut, dapat disebutkan bahwa wirausaha adalah orang yang memiliki dorongan untuk melakukan usaha-usaha kreatif dan inovatif untuk menciptakan sesuatu yang baru yang bermanfaat bagi pelanggan dengan meramu sumber daya untuk menemukan peluang dan perbaikan hidup.

Minat wirusaha tidak sama antara satu dengan yang lain. Menurut Alma (2011) ketidaksamaan wirausaha tersebut dipengaruhi adanya latar belakang yang berbeda, antara lain: (1) lingkungan keluarga semasa kecil, (2) pendidikan, (3) nilai-nilai (values) personal, (4) usia, (5) riwayat pekerjaan. Dipertegas oleh Nabi dan Holden (2008) bahwa niat kewirausahaan siswa juga dapat digunakan untuk mengembangkan program pendidikan yang lebih relevan dan sikap yang mendukung niat kewirausahaan dapat dipelajari dan berdasarkan pengalaman.

Menurut Hytti, et.al. (2010) niat kewirausahaan hanya bisa sebagian menjelaskan keputusan memulai yang sebenarnya, karena biasanya ada jeda waktu yang signifikan antara niat awal dan perilaku aktual. Minat wirausaha siswa dapat diketahui dari ucapan/pengungkapan, tindakan/perbuatan, dan dengan menjawab sejumlah pertanyaan. 
Suryana (2014) mengemukakan ciri-ciri wirausaha sebagai berikut (1) Penuh percaya diri. Kepercayaan diri bersifat internal, sangat relatif, dinamis, dan banyak ditentukan oleh kemampuan untuk memulai, melaksanakan, dan menyelesaikan suatu pekerjaan. Orang yang memiliki kepercayaan diri selalu memiliki komitmen, artinya memiliki nilai keyakinan, optimisme, individualis, dan ketidakbergantungan terhadap sesuatu. (2) Memiliki inisiatif. Artinya harus cekatan dalam bertindak, mampu melakukan beberapa hal sekaligus dalam satu waktu. Sehingga seorang wirausaha akan mampu menciptakan sendiri peluang, yaitu dengan menciptakan sesuatu yang baru dan berbeda, dan sesuatu yang lebih bermanfaat serta mudah digunakan. (3) Memiliki motif berprestasi. Artinya selalu berprinsip berorientasi pada hasil, apa yang dilakukan merupakan usaha maksimal untuk menghasilkan nilai maksimal. Dorongan untuk selalu berprestasi tinggi harus ada dalam diri seorang wirausahawan karena dapat membentuk mental yang selalu lebih unggul dan mengerjakan segala sesuatu melebihi standar yang ada. (4) Memiliki jiwa kepemimpinan. Artinya, seorang wirausahawan yang berhasil memiliki sifat kepemimpinan selalu ingin tampil berbeda, menjadi yang pertama, dan lebih menonjol. Dengan jiwa kepemimpinan yang dimiliki, wirausahawan selalu menampilkan produk dan jasa-jasa baru dan berbeda sehingga menjadi pelopor dalam proses produksi ataupun pemasaran. (5) Berani mengambil resiko. Artinya, seorang wirausahawan harus berani mengambil resiko. Semakin besar resiko yang dihadapi, maka semakin besar pula kemungkinan dan kesempatan untuk meraih keuntungan yang lebih besar. Sebaliknya, semakin kurang berani menghadapi resiko, maka kemungkinan keberhasilan juga semakin sedikit. Resiko-resiko tersebut harus diperhitungkan lebih dahulu. Berani menghadapai resiko yang telah diperhitungkan sebelumnya merupakan kunci awal dalam berusaha karena hasil yang akan dicapai akan proporsional dengan resiko yang akan diambil.

Dari beberapa pendapat di atas, dapat disebutkan bahwa minat wirausaha siswa adalah dorongan yang terdapat pada diri siswa untuk melakukan prestasi, mau dan mampu memanfaatkan kesempatan serta peluang, untuk mencapai tujuan yang dikehendaki sendiri dengan mengoptimalkan kemampuan serta potensi diri secara penuh, untuk memperoleh manfaat dan keuntungan secara maksimal serta untuk membantu masyarakat dengan usaha-usaha konkrit. Dengan demikian indikator dari minat wirausaha siswa antara lain (1) penuh percaya diri; (2) memiliki inisiatif; (3) memiliki motif berprestasi; (4) memiliki jiwa kepemimpinan; (5) berani mengambil resiko.

Seidel dan Richard (2007) dalam jurnalnya menyebutkan belajar adalah serangkaian proses konstruktif di mana individu siswa (sendiri/sosial) membangun, mengaktifkan, menguraikan, dan mengatur struktur pengetahuan. Menurut Slameto (2010) terdapat enam ciri-ciri perubahan tingkah laku dalam pengertian belajar, antara lain: (a) perubahan terjadi secara wajar; (b) perubahan dalam belajar bersifat kontinyu dan fungsional; (c) perubahan dalam belajar bersifat positif dan aktif; (d) perubahan dalam belajar bukan bersifat sementara; (e) perubahan dalam belajar bertujuan dan terarah; (f) perubahan mencakup seluruh aspek tingkah laku. Dijelaskan pula adanya faktor-faktor yang mempengaruhi belajar siswa, yaitu (1) Faktor intern, terdiri dari: (a) Faktor jasmaniah, meliputi faktor kesehatan dan cacat tubuh; (b) Faktor psikologis, meliputi intelegensi, perhatian, minat, bakat, motif, kematangan, dan kesiapan; (c) 
Faktor kelelahan, meliputi kelelahan jasmani dan rohani. (2) Faktor ekstern, terdiri dari: (a) Faktor keluarga, meliputi cara orang tua mendidik, relasi antar anggota keluarga, dan suasana rumah, keadaan ekonomi keluarga, pengertian orang tua, dan latar belakang kebudayaan; (b) Faktor sekolah, meliputi metode mengajar, kurikulum, relasi guru dan siswa, disiplin sekolah, alat pengajaran, standar pelajaran di atas ukuran, keadaan gedung, metode mengajar, dan tugas rumah; (c) Faktor masyarakat, meliputi kegiatan siswa dalam masyarakat, mass media, teman bergaul, dan bentuk kehidupan masyarakat.

Untuk mengukur prestasi belajar siswa diperlukan adanya evaluasi. Secara garis besar tujuan evaluasi pendidikan adalah untuk mendapat data pembuktian yang akan menunjukkan sampai sejauh mana tingkat kemampuan dan keberhasilan siswa dalam pencapaian tujuan kurikuler (Poerwati, dkk. 2013). Selain itu berdasarkan Undang-Undang Sistem Pendidikan Nasional Nomor 20 Tahun 2003 Pasal 58 (1) evaluasi prestasi belajar peserta didik dilakukan untuk memantau proses, kemajuan, dan perbaikan hasil belajar peserta didik secara berkesinambungan. Menurut Poerwati, dkk. (2013) kunci pokok untuk memperoleh ukuran dan data prestasi belajar siswa adalah dengan mengetahui garis-garis besar indikator (penunjuk adanya prestasi tertentu) dikaitkan dengan jenis prestasi yang hendak diungkapkan atau diukur. Rasyid dan Mansur (2007) menyampaikan bahwa prestasi belajar akan bermanfaat bagi masyarakat bila pada lulusan memiliki perilaku dan pandangan yang positif dalam ikut mensejahterakan dan menentramkan masyarakat. Berdasarkan Peraturan Menteri Pendidikan dan Kebudayaan No. 81A tentang Implementasi Kurikulum 2013, penilaian setiap mata pelajaran meliputi kompetensi pengetahuan, kompetensi keterampilan, dan kompetensi sikap.

Tujuan kurikulum 2013 menurut Peraturan Menteri Pendidikan dan Kebudayaan Nomor 70 Tahun 2013 Tentang Kerangka dasar dan Struktur Kurikulum SMK/MAK, untuk mempersiapkan manusia Indonesia agar memiliki kemampuan hidup sebagai pribadi dan warga negara yang beriman, produktif, kreatif, inovatif, dan afektif serta mampu berkontribusi pada kehidupan masyarakat, berbangsa, bernegara, dan peradaban dunia. Dalam Undang-Undang Sistem Pendidikan Nasional Nomor 20 Tahun 2003 disebutkan bahwa mata pelajaran produktif adalah kelompok mata pelajaran yang berfungsi membekali peserta didik agar memiliki kompetensi kerja sesuai Standar Kompetensi Kerja Nasional Indonesia (SKKNI). Pemilihan peminatan bidang keahlian dan paket keahlian dilakukan saat siswa mendaftar pada SMK/MAK. Adapun mata pelajaran produktif kelompok $\mathrm{C}$ (peminatan), terdiri dari kelompok mata pelajaran produktif: (a) dasar paket keahlian (C1); (b) dasar paket keahlian (C2); (c) paket keahlian (C3). Pilihan pendalaman keahlian mata pelajaran produktif paket keahlian (C3) dilakukan pada semester tiga, berdasarkan nilai rapor dan/atau rekomendasi guru BK dan/atau hasil penempatan (placement) oleh psikolog, serta merupakan hasil sinkronisasi dengan pihak diluar sekolah, yaitu pihak DU/DI. Pada penelitian ini mata pelajaran produktif yang dijadikan tolok ukur adalah kelompok mata pelajaran produktif paket keahlian (C3) pada Bidang Keahlian Bismen yang terdiri dari program keahlian Administrasi, Keuangan, dan Tata Niaga, sesuai dengan program keahlian yang ada di SMKN 1 Surabaya, SMKN 4 Surabaya, dan SMKN 10 Surabaya tahun pelajaran 2014/2015, serta sesuai 
dengan kurikulum SMK 2013, yang merupakan hasil sinkronisasi antara pihak sekolah dan pihak DU/DI/Instansi.

Berdasarkan beberapa pendapat tentang prestasi belajar, undang-undang dan peraturan pemerintah tentang mata pelajaran produktif, dapat disebutkan bahwa yang dimaksud dengan prestasi belajar mata pelajaran produktif adalah hasil evaluasi yang merupakan laporan penilaian berupa skor (angka) dan predikat sesuai dengan Kriteria Ketuntasan Minimal (KKM) yang telah ditentukan untuk kelompok mata pelajaran produktif paket keahlian (C3) siswa kelas XI semester satu pada Bidang Keahlian Bismen dengan program keahlian Administrasi, Keuangan, dan Tata Niaga, yang diperoleh dari guru mata pelajaran produktif setelah siswa mengikuti proses kegiatan pembelajaran, serta merupakan prestasi belajar siswa selama satu semester pada tahun pelajaran 2014/2015.

Fatukawati (2013) menyebutkan bahwa efektivitas adalah keadaan yang menunjukkan sejauh mana apa yang direncanakan dapat tercapai, semakin banyak rencana yang dapat dicapai semakin efektif pada kegiatan tersebut. hal tersebut dipertegas oleh Amri (2013) yang menyebutkan bahwa efektivitas berasal dari kata efektif, yang berarti dapat membawa hasil, berhasil guna, ada efeknya, pengaruhnya, akibatnya, kesannya. Menurut Jacobsen, et.al. (1993), pembelajaran dapat dikatakan efektif apabila siswa secara aktif dilibatkan dalam pengorganisasian dan penemuan informasi (pengetahuan). Siswa tidak hanya secara pasif menerima pengetahuan dari guru, dengan demikian dalam proses pembelajaran sangat perlu diperhatikan keterlibatan siswa dalam pengorganisasian pelajaran dan pengetahuan. Menurut Slavin (2011), keefektifan pengajaran terdiri dari empat unsur yang disebut model QAIT, antara lain: (1) Quality (kualitas pembelajaran), yaitu tingkat penyajian informasi atau keterampilan sedemikian hingga siswa dapat mudah mempelajarinya; (2) Appropriateness (tingkat pengajaran yang tepat), yaitu kesesuaian tingkat pembelajaran, yang merupakan tingkat keyakinan guru terhadap kesiapan siswa untuk menerima materi yang belum pernah mereka pelajari; (3) Incentive (insentif), yaitu sejauh mana upaya guru dalam memotivasi siswa untuk mengerjakan tugas belajar dan materi yang diberikan; (4) Time (waktu), yaitu lamanya waktu yang diberikan kepada siswa untuk mempelajari materi yang disajikan.

Berdasarkan pendapat di atas, dapat disebutkan bahwa efektivitas adalah seberapa besar tingkat keberhasilan yang dapat diraih (dicapai) dari suatu usaha tertentu oleh guru sesuai dengan tujuan yang ingin dicapai dengan ukuran yang pasti, dengan melibatkan siswa secara aktif di dalam aktifitas pembelajaran.

Newman, et.al (2004) menyebutkan bahwa laboratorium tidak hanya digunakan untuk kelompok bidang studi eksakta (sain dan teknologi) tetapi terdapat juga pada kelompok bidang studi IPS, maupun dunia pendidikan. Adanya laboratorium di instansi pendidikan merupakan sarana penunjang pelaksanaan tugas-tugas pokok sekolah dalam bidang tersebut, serta sebagai sarana untuk mempersiapkan dan menyediakan media pengajaran untuk melayani kepentingan. Pada lembaga pendidikan laboratorium digunakan siswa melakukan kegiatan praktikum untuk memperoleh pengetahuan praktis sesuai dengan paket keahlian yang dipelajarinya. Belajar siswa dipengaruhi oleh motivasi siswa, yang termotivasi untuk belajar akan bersungguh-sungguh dalam mempelajari sesuatu. Melalui kegiatan laboratorium, siswa diberi kesempatan untuk memenuhi dorongan rasa ingin tahu dan ingin bisa. 
Kozma dkk (dalam Fatukawati, 2013) menyebutkan, laboratorium digunakan untuk kegiatan pengajaran yang memerlukan praktek keterampilan tertentu dan atau pengalaman-pengalaman langsung bagi siswa. Menurut Jailani (dalam Rohman, 2013) laboratorium merupakan pusat sumber belajar (resources centre/learning resources centre) yang berfungsi melayani berbagai kebutuhan individual suatu fakultas, sekolah atau akademi. Pemanfaatan laboratorium optimasi ruangan adalah suatu usaha untuk mengoptimalkan pemakaian ruangan sehingga laboratorium secara optimal memberikan faedah dan penunjang pencapaian tujuan ruangan. Karakteristik ruangan laboratorium yang dikelola dengan baik antara lain efektif, efisien, sehat dan aman, peralatan/fasilitas selalu siap pakai dan aman, seluruh aktivitas laboratorium mudah di kontrol, serta memenuhi kebutuhan psikologis. Dipertegas pula dalam Peraturan Menteri Pendidikan dan Kebudayaan Nomor 70 Tahun 2013 tentang Kerangka Dasar dan Struktur Kurikulum SMK/MAK, bahwa kurikulum 2013 menganut: (1) Pembelajaan yang dilakukan guru (taught curriculum) dalam bentuk proses yang dikembangkan berupa kegiatan pembelajaran di sekolah, kelas, dan masyarakat; (2) Pengalaman belajar langsung peserta didik (learned-curriculum) sesuai dengan latar belakang, karakteristik, dan kemampuan awal peserta didik.

Dari beberapa pendapat di atas, dapat disebutkan bahwa laboratorium adalah ruangan yang digunakan sebagai pusat sumber belajar, yang dilengkapi dengan berbagai peralatan untuk melakukan proses kegiatan teori maupun praktek sesuai paket keahlian yang diminati siswa untuk mencapai tujuan yang ingin dicapai secara efektif.

Dalam kurikulum 2006 disebutkan bahwa agar siswa dapat belajar tuntas perlu dikembangkan prinsip pembelajaran, (1) Learning by doing, yaitu belajar melalui aktivitas/kegiatan nyata, yang memberikan pengalaman belajar bermakna yang dikembangkan menjadi pemelajaran berbasis produksi; (2) Individualized learning, yaitu pemelajaran dengan memperhatikan keunikan setiap individu. Dalam kurikulum 2006 dijelaskan pula adanya tujuan pendidikan pelatihan usaha antara lain: (1) Menyiapkan siswa agar menjadi manusia produktif, mampu bekerja sesuai dengan kompetensi dalam program keahlian yang dipilihnya; (2) Menyiapkan siswa agar mampu memilih karier, ulet dan gigih dalam berkompetensi, beradaptasi di lingkungan kerja, dan mengembangkan sikap profesional dalam bidang keahlian yang diminatinya; (3) Membekali siswa dengan ilmu pengetahuan, teknologi, dan seni, agar mampu mengembangkan diri di kemudian hari baik secara mandiri maupun melalui jenjang pendidikan yang lebih tinggi. (4) Membekali siswa dengan kompetensi-kompetensi yang sesuai dengan program keahlian yang dipilih.

Jailani (dalam Rohman, 2013) menyebutkan bahwa pelatihan usaha juga merupakan pusat sumber belajar (resources centre/learning resources centre) berfungsi sebagai sumber belajar dan mengajar, sebagai metode pengamatan dan metode percobaan, sebagai prasarana pendidikan atau sebagai wadah dalam proses belajar mengajar. Kegiatan pelatihan usaha dipertegas pula dengan adanya Peraturan Menteri Pendidikan dan Kebudayaan Nomor 65 tahun 2013 Tentang Standar Proses Pendidikan Dasar dan Menengah bahwa pembelajaran berlangsung di rumah, di sekolah, dan di masyarakat.

Dengan demikian dapat disimpulkan bahwa efektivitas laboratorium pelatihan usaha adalah tercapainya secara efektif sesuai ukuran yang telah 
ditetapkan tujuan yang diinginkan, melalui pusat sumber belajar baik yang berada di sekolah, sehingga SMK mampu mempersiapkan lulusan yang berkualitas dan mampu bersaing di masyarakat sesuai dengan program keahliannya.

Nabi dan Holden (2008) dalam Graduate Entrepreneurship: Intentions, Education and Training, menyebutkan bahwa pendidikan dan pelatihan tersebut ditandai dengan ambiguitas dan ketidakpastian tentang apa dan bagaimana harus diajarkan. Dalam jurnalnya, Rohman (2006) menyebutkan bahwa unit produksi di SMK merupakan alternatif tempat pelatihan usaha SMK. Melalui pelatihan usaha diharapkan siswa dapat memiliki kesiapan saat harus melaksanakan kegiatan prakerin di DU/DI.

Dikemukakan pula bahwa salah satu upaya untuk meningkatkan relevansi dan efektivitas pendidikan dengan kemampuan lulusan SMK untuk bekerja dan menciptakan lapangan kerja, dalam bentuk kompetensi kecakapan hidup (lifeskill). Kecakapan hidup yang dimaksud adalah unsur-unsur yang harus ditumbuhkan dalam diri siswa, antara lain: (1) Perangkat keras kecakapan hidup (hardskill), berupa fisik, terlihat dan terpakai dan dapat ditingkatkan melalui pengalaman yang dilatihkan secara berulang-ulang; (2) Perangkat lunak kecakapan hidup (softskill), bersifat non fisik, seperti sikap dan etos kerja yang termasuk dalam ranah afektif; (3) Kecakapan berwirausaha, dalam hal ini lebih banyak ditekankan pada soft component kepribadian seperti : (a) kemandirian; (b) kepemimpinan; (c) kejujuran; (d) rasa percaya diri; (e) kemampuan untuk mengatasi masalah (problem solving); dan (f) tidak mudah putus asa.

Berdasarkan pandangan tersebut, efektivitas laboratorium pelatihan usaha dapat diketahui melalui faktor-faktor berikut: (1) Program pelatihan perangkat keras, untuk melatih keterampilan vokasional. Fasilitas fisik berupa adanya peralatan/fasilitas laboratorium yang mendukung kelancaran proses pembelajaran, serta adanya sumber belajar, seperti modul dan job instruction. (2) Program pelatihan soft Skill, merupakan komponen non fisik yang harus dimiliki siswa, yaitu adanya disiplin kerja, serta adanya kesehatan dan keselamatan kerja. (3) Program pelatihan kecakapan berwirausaha. Pelatihan diarahkan pada penanaman jiwa wirausaha antara lain percaya diri dan berani mengambil resiko. (4) Pelatihan problem solving. Pada pelatihan problem solving siswa dikonfrontasi secara langsung dengan masalah yang ada dan dilibatkan dalam upaya-upaya mengatasinya. (5) Instruktur bersertifikasi kompetensi industri. Bahwa keberhasilan suatu pelatihan di industri sangat tergantung pada kemampuan tenaga edukatif yang sesuai dan berskala industri. Untuk itu kompetensi guru tersebut hendaknya diujikan di DU/DI dan dilegalkan dengan Sertifikat Kompetensi dari DU/DI. Alternatif lainnya adalah mengunakan atau meminjam tenaga pelatih atau instruktur dari DU/DI. Dengan demikian indikator efektivitas laboratorium pelatihan usaha, antara lain (1) fasilitas fisik; (2) fasilitas non fisik; (3) melatih kecakapan wirausaha; (4) melatih pemecaham masalah (problem solving); (5) instruktur bersertifikasi kompetensi.

Dengan demikian dapat dijelaskankan bahwa tujuan penelitian ini adalah (1) untuk menganalisis pengaruh prestasi belajar mata pelajaran produktif terhadap minat wirausaha siswa di SMK Negeri Surabaya; (2) untuk menganalisis efektivitas laboratorium tempat pelatihan usaha terhadap minat wirausaha siswa di SMK Negeri Surabaya; dan (3) menganalisis pengaruh prestasi belajar mata 
pelajaran produktif dan efektivitas laboratorium pelatihan usaha terhadap minat wirausaha siswa.

\section{METODE PENELITIAN}

Penelitian ini menggunakan metode penelitian survey. Menurut tingkat eksplanasinya, adalah penelitian asosiatif/hubungan, bertujuan untuk mengetahui hubungan dua variabel atau lebih. Bentuk hubungan antara variabel adalah hubungan interaktif/resiprokal yaitu hubungan yang saling mempengaruhi. Variabel penelitian terdiri dari prestasi belajar mata pelajaran produktif $\left(\mathrm{X}_{1}\right)$ dan efektivitas laboratorium pelatihan usaha $\left(\mathrm{X}_{2}\right)$ sebagai variabel independen, serta minat wirausaha siswa (Y) sebagai variabel dependen. Populasi berjumlah 693 yang berasal dari siswa kelas XI Bismen semester satu di SMKN 1 Surabaya, SMKN 4 Surabaya, dan SMKN 10 Surabaya. Sampel penelitian ditentukan dengan rumus dari Taro Yamane dengan tingkat presisi $5 \%$. yaitu: $\hbar .=\frac{\mathbb{N}}{N \cdot \Omega^{2}+1}$ Teknik sampling menggunakan proporsional random sampling berjumlah 254 siswa. Data diolah dengan program IBM SPSS Statistics 22.

Metode pengumpulan data menggunakan angket dengan skala Likert dan dokumen. Untuk uji validasi angket, uji signifikansi dilakukan dengan membandingkan nilai $r$ hitung dengan $r$ tabel untuk degree of freedom $(\mathrm{df})=\mathrm{n}-2$. Besarnya $\mathrm{df}=252$ dan alpha $5 \%$ sebesar $r$ tabel sebesar 0,138 . Berdasarkan hasil uji validasi pada variabel independen $\mathrm{X}_{2}$ dan variabel dependen $\mathrm{Y}$, Corrected ItemTotal Correlation yang dihasilkan tiap sub indikator variabel $\mathrm{X}_{2}$ dan variabel $\mathrm{Y}$ adalah lebih besar dari $\mathrm{r}$ tabel $(0,138)$, sehingga angket dinyatakan valid. Uji reliabilitas diukur melalui uji statistik Cronbach Alpha (á), dan variabel dinyatakan reliabel jika memberikan nilai Cronbach Alpha (á) lebih besar dari 0.60. Berdasarkan hasil uji reliabilitas diketahui nilai Alpha Cronbach's pada variabel independen $\left(\mathrm{X}_{2}\right)$ sebesar 0.701 dan variabel dependen $(\mathrm{Y})$ sebesar 0.819, adalah lebih besar dari 0.60, dengan demikian kedua variabel tersebut adalah reliabel.

Teknik analisa data menggunakan uji statistik linear berganda untuk menguji pengaruh variabel independen terhadap variabel dependen, uji $\mathrm{F}$ untuk menguji signifikansi secara simultan variabel independen terhadap variabel dependen, serta uji t untuk menguji signifikansi secara parsial pengaruh variabel independen terhadap variabel dependen.

\section{HASIL DAN PEMBAHASAN}

Persamaan regresi linear berganda berdasarkan hasil analisis variabel prestasi belajar mata pelajaran produktif $\left(\mathrm{X}_{1}\right)$, efektivitas laboratorium pelatihan usaha $\left(\mathrm{X}_{2}\right)$ terhadap minat wirausaha siswa $(\mathrm{Y})$ di SMK Negeri Surabaya, adalah:

$$
\mathrm{Y}=16,717+1,463 \mathrm{X}_{1}+0,440 \mathrm{X}_{2}+\mu
$$

Dari persamaan regresi tersebut dapat dijelaskan sebagai berikut: a) Nilai konstanta $(\alpha)$ yang dihasilkan adalah sebesar 16,717 (positif). Hal ini menjelaskan bahwa terdapat pengaruh positif variabel independen (prestasi belajar mata pelajaran produktif dan efektivitas laboratorium pelatihan usaha). Bila variabel independen naik atau berpengaruh dalam satuan, maka variabel minat wirausaha 
siswa akan naik atau terpenuhi. b) Nilai koefisien regresi prestasi belajar mata pelajaran produktif $\left(\mathrm{X}_{1}\right)$ adalah sebesar 1,463 (positif) terhadap variabel minat wirausaha siswa (Y). Hal ini menjelaskan bahwa jika prestasi belajar mata pelajaran produktif $\left(\mathrm{X}_{1}\right)$ mengalami kenaikan satu satuan, maka variabel minat wirausaha siswa akan mengalami peningkatan sebesar 1,463 (14,63\%). Koefisien bernilai positif artinya antara prestasi belajar mata pelajaran produktif $\left(\mathrm{X}_{1}\right)$ dan variabel minat wirausaha siswa (Y) terdapat hubungan positif. c) Nilai koefisien regresi variabel efektivitas laboratorium pelatihan usaha $\left(\mathrm{X}_{2}\right)$ adalah sebesar 0,440 (positif) terhadap variabel minat wirausaha siswa (Y) artinya jika efektivitas laboratorium pelatihan usaha $\left(\mathrm{X}_{2}\right)$ mengalami kenaikan satu satuan, maka variabel minat wirausaha siswa akan mengalami peningkatan sebesar 0,440 (4,4\%). Koefisien bernilai positif artinya antara efektivitas laboratorium pelatihan usaha $\left(\mathrm{X}_{2}\right)$ dan variabel minat wirausaha siswa $(\mathrm{Y})$ terdapat hubungan positif.

Nilai $t$ hitung pada prestasi belajar mata pelajaran produktif $\left(\mathrm{X}_{1}\right)$ sebesar 7,337 lebih besar dari $\mathrm{t}$ tabel pada tingkat signifikan alpha 5\% sebesar 1,96. Begitu juga dengan probabilitas kesalahan sebesar 0,000 lebih kecil dari 5\%. Ini berarti Ho ditolak dan $\mathrm{Ha}$ diterima, maka secara parsial prestasi belajar mata pelajaran produktif $\left(\mathrm{X}_{1}\right)$ berpengaruh signifikan pada minat wirausaha siswa $(\mathrm{Y})$ di SMK Negeri Surabaya. Hal ini menunjukkan bahwa antara variabel prestasi belajar mata pelajaran produktif $\left(\mathrm{X}_{1}\right)$ dan variabel minat wirausaha siswa $(\mathrm{Y})$ terdapat hubungan positif. Berdasarkan nilai koefisien regresi, pengaruh variabel prestasi belajar mata pelajaran produktif $\left(\mathrm{X}_{1}\right)$ terhadap variabel minat wirausaha siswa $(\mathrm{Y})$ adalah sebesar $14,63 \%$.

Hasil penelitian ini sejalan dengan penelitian terdahulu yang dilakukan oleh Nugroho (2013) dalam penelitiannya yang berjudul "Pengaruh Prestasi Belajar Kewirausahaan Terhadap Minat Berwirausaha Siswa SMK Pancasila I Kutoarjo", yang menyimpulkan bahwa prestasi belajar memiliki pengaruh yang positif dan signifikan terhadap minat berwirausaha, dan secara individual minat berwirausaha dapat meningkat dengan meningkatnya prestasi belajar. Hal tersebut tampak pada uji hipotesis diperoleh $\mathrm{p}=0,015<0,05$, berarti prestasi belajar berpengaruh positif dan signifikan terhadap minat berwirausaha siswa SMK Pancasila I Kutoarjo. Besarnya kontribusi pengaruh prestasi belajar terhadap minat berwirausaha bagi siswa SMK Pancasila 1 Kutoarjo sebesar 99,6\%, sedangkan lainnya dipengaruhi oleh faktor lain.

Hasil penelitian ini juga sesuai dengan teori Gestalt (Slameto, 2010) yang menyebutkan bahwa belajar lebih berhasil bila berhubungan dengan minat, keinginan, dan tujuan siswa. Hal itu terjadi bila banyak berhubungan dengan apa yang diperlukan dalam kehidupan sehari-hari. Begitu pula teori yang dikemukakan Slameto (2010) bahwa belajar ialah suatu proses yang dilakukan seseorang untuk memperoleh suatu perubahan tingkah laku yang baru secara keseluruhan, sebagai hasil pengalamannya sendiri dalam interaksi dengan lingkungannya. Pada penelitian ini pengukuran prestasi belajar mata pelajaran produktif berdasarkan rata-rata dari komponen Pengetahuan $\left(\mathrm{X}_{1.1}\right)$ dan komponen Keterampilan $\left(\mathrm{X}_{1.2}\right)$. Hal tersebut sependapat dengan Kirkpatrick (dalam Rasyid, 2007) yang menyarankan tiga komponen yang harus dievaluasi dalam pembelajaran, yaitu pengetahuan yang dipelajari, keterampilan apa yang dikembangkan, dan sikap yang perlu diubah. 
Berdasarkan prestasi belajar mata pelajaran produktif $\left(\mathrm{X}_{1}\right)$ dari responden sebanyak 254 siswa terdapat rata-rata sebesar 3,16. Dengan nilai koefisien regresi $14,63 \%$ serta diperkuat adanya $\mathrm{R}^{2}$ sebesar $91,3 \%$, maka temuan pada penelitian ini adalah terdapat pengaruh yang positif dan signifikan untuk prestasi belajar mata pelajaran $\left(\mathrm{X}_{1}\right)$ terhadap minat wirausaha siswa $(\mathrm{Y})$. Dengan demikian semakin baik prestasi belajar mata pelajaran produktif siswa akan semakin besar minat siswa untuk berwirausaha.

Nilai $t$ hitung pada efektivitas laboratorium pelatihan usaha $\left(\mathrm{X}_{2}\right)$ sebesar 9,366 lebih besar dari $\mathrm{t}$ tabel pada tingkat signifikan alpha 5\% sebesar 1,96. Begitu juga dengan probabilitas kesalahan sebesar 0,000 lebih kcil dari 5\%. Ini berarti Ho ditolak dan Ha diterima, dengan demikian secara parsial efektivitas laboratorium pelatihan usaha $\left(\mathrm{X}_{2}\right)$ berpengaruh signifikan pada minat wirausaha siswa $(\mathrm{Y}) \mathrm{di}$ SMK Negeri Surabaya. Hal ini menunjukkan bahwa antara variabel efektivitas laboratorium pelatihan usaha $\left(\mathrm{X}_{2}\right)$ terhadap minat wirausaha siswa $(\mathrm{Y})$ terdapat hubungan yang positif. Berdasarkan nilai koefisien regresi, pengaruh efektivitas laboratorium pelatihan usaha $\left(\mathrm{X}_{2}\right)$ terhadap minat wirausaha siswa $(\mathrm{Y})$ adalah sebesar $4,4 \%$.

Hasil penelitian ini sejalan dengan penelitian terdahulu tentang laboratorium pelatihan usaha menurut dari Alsop dan Tompsett (2007), bahwa laboratorium pelatihan usaha dikatakan efektif jika terdapat perubahan untuk semua peserta dalam sistem, yang meningkatkan hasil belajar dari pemahaman bersama antara desainer (guru) dan pelaku (siswa). Keberhasilan dapat direproduksi sebagai praktek yang efektif melalui pengenalan teknologi baru menghasilkan beberapa perubahan dalam perilaku siswa.

Penelitian ini sejalan dengan teori yang dikemukakan oleh Brown (dalam Rohman, 2006) yang menyebutkan bahwa sebuah laboratorium pendidikan industri yang disebutnya sebagai industrial art at school, pelatihan diarahkan pada penanaman jiwa wirausaha yang ulet, pantang menyerah, jujur, percaya diri, tidak mudah putus asa, kepemimpinan. Selain itu hasil penelitian ini juga sesuai dengan landasan teori yang tertuang pada Bab II, tentang efektivitas. Jika dikaitkan dengan laboratorium pelatihan usaha, menurut Amri (2013) maka yang dimaksud dengan efektivitas laboratorium pelatihan usaha adalah pemanfaatan laboratorium pelatihan usaha yang berhasil guna yang berpengaruh pada terjadinya peningkatan terhadap minat wirausaha siswa.

Berdasarkan fakta pada efektivitas laboratorium pelatihan usaha $\left(\mathrm{X}_{2}\right)$ dengan responden sebanyak 254 siswa, bahwa pada indikator melatih pemecahan masalah (problem solving) dengan rata-rata interval sebesar 4,23 termasuk dalam kategori penilaian sangat tinggi. Hal ini menunjukan adanya temuan bahwa indikator melatih pemecahan masalah (problem solving) memberikan kontribusi sangat tinggi terhadap minat wirausaha siswa. Sedangkan pada indikator fasilitas fisik dengan rata-rata interval sebesar 3,86 termasuk dalam penilaian dengan kategori tinggi, tetapi merupakan rata-rata interval yang paling rendah dibandingkan dengan indikator-indikator lainnya pada variabel yang sama. Hal ini menunjukkan adanya temuan bahwa fasilitas fisik kurang signifikan memberikan kontribusi terhadap minat wirausaha siswa, disebabkan karena fasilitas komputer dan sumber belajar berupa modul dan job instruction yang disediakan sekolah jumlahnya tidak sesuai dengan rasio perbandingan jumlah siswa. 
Dari hasil analisis data telah terbukti bahwa terdapat pengaruh yang positif dan signifikan antara efektivitas laboratorium pelatihan usaha berpengaruh terhadap minat wirausaha siswa di SMK Negeri Surabaya. Jika efektivitas laboratorium pelatihan usaha tinggi maka minat wirausaha siswa akan tinggi. Tetapi bila tidak didukung dengan fasilitas fisik yang sangat memadai, minat wirausaha siswa akan rendah.

$\mathrm{F}$ hitung bernilai 32,679 lebih besar dari nilai $\mathrm{F}$ tabel pada tingkat signifikan 5\% $=3,04$. Begitu juga dengan probabilitas kesalahan $=0,000$ lebih kecil dari 5\%. Ini berarti Ho ditolak dan Ha diterima, maka prestasi belajar mata pelajaran produktif $\left(\mathrm{X}_{1}\right)$ dan efektivitas laboratorium pelatihan usaha $\left(\mathrm{X}_{2}\right)$ secara simultan berpengaruh signifikan terhadap minat wirausaha siswa (Y) di SMK Negeri Surabaya. Berdasarkan output uji koefisien determinasi $\left(\mathrm{R}^{2}\right)$, besarnya pengaruh prestasi belajar mata pelajaran produktif $\left(\mathrm{X}_{1}\right)$ dan efektivitas laboratorium pelatihan usaha $\left(\mathrm{X}_{2}\right)$ terhadap minat wirausaha siswa $(\mathrm{Y})$ adalah sebesar 91,3\%. Sisanya sebesar $8,7 \%$ dipengaruhi oleh faktor-faktor lain, selain variabel pengaruh prestasi belajar mata pelajaran produktif dan efektivitas laboratorium pelatihan usaha.

Hasil penelitian ini sejalan dengan penelitian terdahulu dari Rohman (2010) yang tertuang dalam jurnalnya bahwa prestasi belajar siswa yang baik serta pelatihan di laboratorium pelatihan usaha yang disebutnya sebagai industrial art school, dengan ketiga fasilitas pendidikan industri yaitu pelatihan keterampilan fisik, pelatihan kedisipilinan dan etos kerja, dan tenaga edukatif terlatih, sangat efektif untuk pelatihan penanaman jiwa wirausaha siswa yang ulet, pantang menyerah, jujur, percaya diri, tidak mudah putus asa. Hasil penelitian ini juga sesusi dengan hasil penelitian Hytti, et.al. (2010) dalam jurnalnya, bahwa prestasi belajar siswa mendukung dampak positif meningkatkan basis pengetahuan dalam kewirausahaan (tentang kewirausahaan), mengembangkan keterampilan kewirausahaan atau giat siswa atau murid (melalui kewirausahaan) atau memulai sebuah bisnis baru ( kewirausahaan) melalui pelatihan usaha di sekolah.

Penelitian ini juga sesuai dengan landasan teori Bab II, menurut Menurut Sonhaji (dalam Fatukawati, 2013) dengan berkembangnya apresiasi terhadap bentuk pembelajaran pengalaman (experiential forms of learning), praktek laboratorium digunakan lebih intensif dan luas dalam pengajaran. Sedangkan menurut Jailani ( dalam Rohman, 2013) laboratorium merupakan pusat sumber belajar (resources centre/learning resources centre) yang berfungsi melayani berbagai kebutuhan individual suatu fakultas, sekolah atau akademi.

Berdasarkan fakta responden penelitian sebanyak 254 siswa yang menunjukkan bahwa: (1) Prestasi belajar mata pelajaran produktif, rata-rata sebesar 3,16 yang berdasarkan tabel 2.1 memiliki konversi nilai antara 84 dan predikat kompetensi baik; (2) Indikator-indikator efektivitas laboratorium pelatihan usaha, rata-rata sebesar 4,04 dengan kategori tinggi; (3) Indikatorindikator minat wirausaha siswa dengan rata-rata sebesar 4,27 dengan kategori sangat tinggi. Maka terdapat temuan bahwa prestasi belajar mata pelajaran produktif dan efektifitas laboratorium pelatihan usaha berpengaruh signifikan positif terhadap minat wirausaha siswa.

Dengan demikian dari analisis data tersebut telah terbukti bahwa secara simultan terdapat pengaruh signifikan positif prestasi belajar mata pelajaran 
produktif dan efektivitas laboratorium pelatihan usaha terhadap minat wirausaha siswa di SMK Negeri Surabaya.

\section{SIMPULAN}

Simpulan berdasarkan hasil analisis data dan pembahasan: 1) Terdapat pengaruh signifikan positif Prestasi Belajar Mata Pelajaran Produktif terhadap Minat Wirausaha Siswa di SMK Negeri Surabaya. Hal ini berarti bahwa secara parsial naiknya prestasi belajar mata pelajaran produktif berpengaruh naiknya minat wirausaha siswa di SMK Negeri Surabaya. 2) Terdapat pengaruh yang positif dan signifikan Efektivitas Laboratorium Pelatihan Usaha terhadap Minat Wirausaha Siswa di SMK Negeri Surabaya. Adanya temuan bahwa indikator melatih pemecahan masalah (problem solving) memberikan kontribusi sangat tinggi terhadap minat wirausaha siswa, juga adanya temuan bahwa fasilitas fisik kurang signifikan memberikan kontribusi terhadap minat wirausaha siswa. Hal ini dikarenakan fasilitas komputer dan sumber belajar berupa modul dan job instruction yang disediakan jumlahnya tidak sesuai dengan rasio perbandingan jumlah siswa. 3) Terdapat pengaruh signifikan positif Prestasi Belajar Mata Pelajaran Produktif dan Efektivitas Laboratorium Pelatihan Usaha terhadap Minat Wirausaha Siswadi SMK Negeri Surabaya.

Saran untuk simpulan, antara lain (1) Meningkatkan kuantitas praktek pada mata pelajaran produktif, sehingga terjadi peningkatan kualitas pencapaian hasil belajar siswa, dengan melibatkan siswa dalam proses pembelajaran interaksi dengan komponen pembelajaran lainnya (yaitu konten pembelajaran, kegiatan pembelajaran, rekan mitra sebaya, tutor, dan instruktur) agar minat wirausaha siswa lebih baik lagi. (2) Meningkatkan pelatihan pemecahan masalah (problem solving) siswa melalui pengalaman yang dilatihkan secara berulang-ulang di laboratorium pelatihan usaha, serta menambah jumlah fasilitas komputer dan fasilitas sumber belajar berupa modul dan job instruction yang disediakan sekolah sesuai dengan rasio perbandingan jumlah siswa, agar minat wirausaha siswa dapat tumbuh dan berkembang dengan baik. (3) Meningkatkan penanaman nilai-nilai kewirausahaan dengan memotivasi siswa untuk lebih kreatif dan inovatif, mengasah kemampuan siswa untuk bertindak sebagai pemimpin dalam kegiatan, serta mampu bekerja sama dengan orang lain dalam tim, melalui pembelajaran pada mata pelajaran produktif maupun di laboratorium pelatihan usaha sehingga dapat menghasilkan lulusan yang tangguh dan siap berwirausaha di era globalisasi MEA (Masyarakat Ekonomi Asia).

\section{DAFTAR RUJUKAN}

Abdullah, A.Z., \& Norhlilmatun, S. 2013. Factor That influence the Interest of Youth in Agricultural Entrepreneurship. International Journal of Business and Social Science. Vol.4, No.3 March, 2013.

Amri, S. 2013. Pengembangan dan Model Pembelajaran dalam Kurikulum 2013. Jakarta: Prestasi Pustaka Raya.

Alma, B. 2011. Kewirausahaan Edisi Revisi. Cetakan Ketujuhbelas. Bandung: Penerbit Alfabeta. 
Al-Mighwar, M. 2011. Psikologi Remaja. Cetakan Kedua. Bandung: Pustaka Setia.

Alsop, G., \& Tompsett, C. 2007. From Effect to Effectiveness: the Missing Research Questions. Paper presented at International Forum of educational technology \& Society (IFETS). October, 2007.

Arasti, Z., Falavarjani, M.K. \& Imanipur, N. 2012. A Study of Teaching Methods in Entrepreneurship Education for Graduate Students. Journal Higher Education Studies Vol.2, No.9, pp. 2-10.

Arikunto, S. 2010. Prosedur Penelitian Suatu Pendekatan Praktek. Cetakan Keempatbelas. Jakarta: PT. Rineka Cipta.

Cheung Chi-Kim., \& Au, E. 2010. Running A Small Business By Students In A Secondary School: Its Impact On Learning About Entrepreneurship. Journal of Entrepreneurship Education. Vol.13, No.19, pp. 45-63.

Davey, T., \& Plewa, C. 2011. Entrepreneurship Perceptions And Career Intentions Of International Students. Journal: Technology, Comprehensive Works, Education. Vol.53, No.5 2011, pp. 335-352.

Faozi, A. 2013. Pengaruh Praktek Kerja Industri ( Prakerin ) Terhadap Motivasi Belajar Siswa Kelas XI Teknik Otomotif Kendaraan Ringan. Jurnal Ilmiah IKIP Veteran Semarang. Vol.3, No.2 November, 2013, pp.127.

Fatukawati, I. 2013. Evaluasi Keefektifan Fungsi-fungsi Manajemen Laboratorium IPA di SMA Hang Tuah 1 Surabaya (Evaluasi Model Fungsi CIPP Stufflebeam) (Tesis magister pendidikan tidak dipublikasikan). Universitas Negeri Surabaya.

Fradani, A. C. 2014. Pengaruh Kecerdasan Adversitas, Pendidikan Kewirausahaan Dalam Keluarga, Dukungan Keluarga, Dan Efikasi Diri Pada Intentensi Berwirausaha Siswa SMK Negeri 2 Nganjuk (Tesis magister pendidikan tidak dipublikasikan). Universitas Negeri Surabaya.

Gallant, M. \& Majumdar, S. 2010. Outlook of Female Students Towards Entrepreneurship. Journal: Business And Economics, Education, Sociology. Vol.3, No.3, 2010, pp. 218-230.

Gujarati, D. 1995. Ekonometrika Dasar (terjemahan Sumarno Zain), Jakarta: Erlangga.

Gujarati, D. 2003. Basic Econometric. Mc.Grawhill. New York.

Ghofur, M.A. 2012. Kredibilitas dan Otensitas Guru Kewirausahaan Terhadap Karakter Kewirausahaan Siswa SMK Negeri di Surabaya (Tesis magister pendidikan tidak dipublikasikan). Universitas Negeri Surabaya.

Ghozali, I. 2009. Aplikasi Multivariate Dengan Program SPSS. Cetakan IV. Semarang: Badan Penerbit Undip.

Ghozali, I. 2014. Ekonometrika Teori, Konsep dan Aplikasi Dengan IBM SPSS 22. Semarang: Badan Penerbit Undip.

Hytti, U., Stenholm, P., Heinonen, J., \& Seikkula-Leino, J. 2010. Perceived Learning Outcomes in Entrepreneurship Education. Journal Education \&Training. Vol.52, pp. 587-606.

Hurlock, E.B. 2010. Perkembangan Anak. Jilid 2. Penerjemah Meitasari Tjandrasa. Edisi Keenam. Jakarta: Penerbit Erlangga.

Hussain, J.G., Scott, J.M., \& Matlay, H. 2010. The Impact of Entrepreneurship Education on Succession in Ethnic Minority Family Firms. Journal Education \& Training. Vol.52, pp. 643-659. 
Iswandari, A. 2013. Pengaruh Motivasi Intrinsik, Pengetahun Kewirausahaan, dan Kepribadian Terhadap Minat Berwirausaha Pada Siswa SMKN 12 Surabaya (Tesis magister pendidikan tidak dipublikasikan). Universitas Negeri Surabaya.

Jacobsen, D.A, Eggen, P. \& Kauchak, D. 1993. Strategis For Teacher, Teaching Content Thinking Skills. Allyn an Bacon Publisher. Boston.

Jerri, N., Kasman, N., \& Rizal, F. 2013. Hubungan Antara Hasil Belajar Kewirausahaan dan Hasil Praktek Kerja Industri Dengan Minat Berwirausaha Siswa Kelas XII SMK Negeri 2 Padang panjang (Tesis magister pendidikan tidak dipublikasikan). Universitas Negeri Padang.

Kobia, M. \& Sikalieh, D. 2010. Towards A Search For The Meaning of Entrepreneurship. Journal of European Industrial Training.Vol.34, No.2 2010, pp. 110-127.

Lim, D.H., \& Morris, M.L. 2009. Learner and Instructional Factors Influencing Learning Outcomes Within a Blended Learning Environment. Journal Educational Technology \& Society. Vol.12 (4), pp. 282-293.

Longenecker, J.G., Carlos, W.M. \& Petty J.W. 2001. Kewirausahaan Manajemen Usaha Kecil. Jakarta: Salemba Empat.

Manuere, F., Danha, K. \& Majoni, T. 2013. Entrepreneurship Attitude and Knowledgement: A Survey of Fourth Year University Students. Interdisciplinary Journal of Contemporary Research in Bussiness. Vol.4, No.9 January, 2013.

Menteri Pendidikan dan Kebudayaan Republik Indonesia. 2013. Permendikbud No. 70 Tahun 2013 Tentang Kerangka Dasar dan Struktur Kurikulum Sekolah Menengah Kejuruan / Madrasah Aliyah Kejuruan. Jakarta: Depdikbud.

Menteri Pendidikan dan Kebudayaan Republik Indonesia. 2013. Permendikbud No. 81A Tahun 2013 Tentang Implementasi Kurikulum. Jakarta: Depdikbud.

Menteri Pendidikan dan Kebudayaan Republik Indonesia. 2013, Permendikbud No. 65 Tahun 2013 Tentang Standar Proses Pendidikan Dasar dan Menengah. Jakarta: Depdikbud.

Meredith, G. G. 2000. Kewirausahaann: Teori dan Praktek. Jakarta: Pustaka Binaman Pressindo

Morissan. Wardani, A.C. \& Hamid, F. (Eds). 2012. Metode Penelitian Survey. Jakarta: Prenada Media Grup.

Nabi, G., \& Holden, R. 2008. Graduate Entrepreneurship: Intentions, Education and Training. Journal Education \& Training. Vol. 50, pp. 545-551.

Nugroho, B. A. 2005. Strategi Jitu Memilih Metode Statistik Penelitian Dengan SPSS. Yogyakarta: Andi.

Nugroho, B. A. 2013. Pengaruh Prestasi Belajar Kewirausahaan Terhadap Minat Berwirausaha Siswa SMK Pancasila I Kutoarjo. Oikonomia: Vol.2 No.2.

Newman, D. \& Cole, M. 2004. Can Scientific Research From the Laboratory be of Any Use to Teachers? ProQuest Education Journals. Vol.43, No.4, pp. 260-267.

Novianti, N.R. 2011. Kontribusi Pengelolaan Laboratorium Dan Motivasi Belajar Siswa Terhadap Efektivitas Proses Pembelajaran (Penelitian Pada SMP Negeri dan Swasta di Kabupaten kuningan Propinsi Jawa Barat) (Tesis magister pendidikan tidak dipublikasikan). Universitas Negeri Surabaya. 
Othman, N. \& Hashim, N. 2012. Readiness Towards Entrepreneurship Education. Journal: Technology. Comprehensive Works, Education. Vol.54,No. 8/9, 2012, pp. 697-708.

Packham, G., Jones, P. \& Miller, C. 2010. Attitudes Towards Entrepreneurship Education: A Comparative Analysis. Journal: Technology. Comprehensive Works, Education. Vol.52, No.8/9, 2010, pp. 568-586.

Poerwati, L.E \& Sofan, A. 2013. Panduan Memahami Kurikulum 2013. Jakarta: PT Prestasi Pustakaraya.

Rasyid, H. \& Mansur. 2007. Penilaian Hasil Belajar. Cetakan pertama. Bandung: CV Wacana Prima.

Riduwan. 2010. Metode dan Teknik Menyusun Tesis. Cetakan ketujuh. Bandung: CV Alfabeta.

Riduwan, S. 2007. Pengantar Statistik Untuk Penelitian Untuk Penelitian Pendidikan, Sosial, Ekonomi, Komunikasi, dan Bisnis. Cetakan kesatu. Bandung: Penerbit Alfabeta.

Riyanti, B. P. D. (2003). Kewirausahaan Dari Sudut Pandang psikologi Kepribadian. Jakarta: Grasindo

Rohman, A. 2006. Pemanfaatan Unit Produksi Sebagai Alternatif Tempat Pelatihan Lifeskill dan Enterpreuner Skill. Pendidikan Teknik Elektro. Universitas Negeri Jakarta. Pevote. Vol.1, No.1 September, 2006, h. 17-21.

Seibert, D.C., Guthrie, J.T. \& Adamo, G. 2004. Improving Learning Outcomes: Integration of Standardized Patients \& Telemedicine Technology. Journal Nursing Education Perspectives. Vol.25, No.5, pp. 232-7.

Seidel, T., \& Richard, J.S. 2007. Teaching Effectiveness Research in the Past Decade: The Role of Theory and Research Design in Disentangling MetaAnalysis Resuls. Review of Educational Research Journal. Vol.77. No.4. pp. 454-459.

Setyowati, D.I. 2013. Pengaruh Pekerjaan Orang Tua dan Keyakinan Diri terhadap Minat Berwirausaha Siswa di SMK Negeri 10 Surabaya (Tesis magister pendidikan tidak dipublikasikan). Universitas Negeri Surabaya.

Slameto. 2010. Belajar dan Faktor-faktor yang Mempengaruhi. Cetakan kelima. Jakarta: PT Rineka Cipta.

Slameto. 2003. Belajar dan Faktor-faktor yang Mempengaruhi. Jakarta: PT Rineka Cipta.

Slavin, R.E. 2011. Psikologi Pendidikan:Teori dan Praktek. Edisi 9. Jilid 1. Jakarta. PT Indeks

Slavin, R.E. 2011. Psikologi Pendidikan:Teori dan Praktek. Edisi 9. Jilid 2. Jakarta. PT Indeks

Sudarmanto, G.R. 2005. Analisis Regresi Linear ganda Dengan SPSS. Jakarta: Graha Ilmu.

Sugiyono. 2009. Metode Penelitian Administrasi. Cetakan ke 17. Bandung: CV. Alfabeta.

Suherman, E. 2010. Desain Pembelajaran Kewirausahaan. Bandung: Alfabeta.

Sukardi. 2009. "Masalah Kebaruan Dalam Penelitian Teknologi Industri Pertanian". Jurnal Teknologi Industri Pertanian. Vol. 19 (2). pp. 115-121

Suryana. 2014. Kewirausahaan Kiat dan Proses Menuju Sukses. Jakarta: Salemba Empat. 
Susanti. 2012. Pengaruh Persepsi Siswa Tentang Pendidikan Kewirausahaan Dan Persepsi Siswa Tentang Praktek Penjualan Konsinyasi Terhadap Minat Berwirausaha Dan Prestasi Belajar Kewirausahaan Siswa Kelas XI Program Studi Pemasaran SMKN 1 Bantul. Jurnal Pendidikan dan Ekonomi Volume 1, Nomor 2 Desember, Tahun 2012.

Tasmuri. 2013. Peningkatan Hasil Belajar Siswa Memproses Entry Jurnal Melalui Pembelajaran Simulasi di Kelas X Akuntansi 4 SMK Negeri 2 Tuban (Tesis magister pendidikan tidak dipublikasikan). Universitas Negeri Surabaya.

Winardi, J. 2004. Entrepreneur \& Entreprenurship. Jakarta: Kencana. 